\title{
Optimize Design Impeller to Increase Efficiency Centrifugal Pump That Functioned as a Turbine Use Computational Fluid Dynamics (CFD)
}

\author{
Akhmad Fauzan Al Ansory ${ }^{1, *}$ Istianto Budhi Rahardja ${ }^{2}$ \\ ${ }^{1}$ Faculty Engineering, Sekolah Tinggi Ilmu Teknik Bina Putera, 46321, Indonesia \\ ${ }^{2}$ Process Technology Plantation Products, Politeknik Kelapa Sawit Citra Widya Edukasi, 17520, Indonesia \\ "Corresponding author.Email: fauzana_pato@yahoo.co.id
}

\begin{abstract}
The energy crisis will be come soon and one of the very potentials of renewable energy is the energy usage of water for micro hydro power plant (PLTMH). A centrifugal pump is used for water turbine from the pump channels. The purpose of the study is knowing the influence of modelling the geometry on the impeller centrifugal pumps that can affect the performance of Pump as Turbine (PAT) with the value of the surface roughness of the impeller $0,16 \mu \mathrm{m}$ using forward blade close impeller model. The method of research analysis design and fluid flow at the impeller by use CFD software. The result of analysis showed the model backward blade close impeller with 5 blades, the impeller entrance angle $\beta 2$ $56.6^{\circ}$ is the optimum results Velocity and pressure distribution more homogeneous.
\end{abstract}

Keywords: Pump as Turbine, Computational Fluid Dynamics, Backward Impeller.

\section{INTRODUCTION}

This time in Indonesian electricity is provided by the State Electricity Company (PLN), but there are still many villages that do not get adequate electricity supply. Many cities and sub-districts rely on PLTD and only operate at night from 18:00 - 24:00 WIB. When the oil is not found, it will go out. According to the 2011 Natural Resources Research and Development Agency (BPPSDA) there are more than 14,198 villages that do not have adequate access to electricity, so it is necessary to find other alternative energy solutions and apply renewable energy to meet these electricity needs [1]. According to the Asian Development Outlook 2012, renewable energy is energy produced from natural sources such as water, sun and wind. This energy source is always available and can always be obtained, and does not harm the environment. This means that renewable resources can be regenerated or renewed in a relatively short time, renewable energy sources such as: biomass, wind, geothermal, solar and water [3]

Pump As Turbine (PAT) technology is able to provide alternative energy solutions for small scale micro hydro manufacturing at an economical and affordable cost [3-4], with the availability of pumps widely on the market and produced on a large scale will facilitate the application of Pump as Turbine on rural areas in Indonesia [2]. The research process that has been carried out is only limited to impeller effectiveness and rotational speed [3-4].

From this background, there is still little information on fluid flow characteristics in a centrifugal pump that functions as a turbine with a certain degree of roughness and the optimal geometric shape of the impeller. In this study, a solution was made to optimize the impeller design to increase the efficiency of a centrifugal pump that functions as a turbine using a Computational Fluid Dynamics (CFD) simulation.

Centrifugal pumps work by converting the mechanical energy from the shaft that moves the blades of the pump, then into kinetic energy and pressure on the fluid. The rotation of the impeller causes a vacuum pressure on the suction side of the pump, as a result of which the flowing fluid is sucked into the impeller [7]. Inside the impeller, the fluid gets accelerated in such a way and is subjected to centrifugal force, so the fluid flows out of the impeller at a certain speed. The exit speed of this fluid will then decrease and turn into pressure energy in the pump housing. The amount of pressure that arises depends on the magnitude of the fluid velocity [6]. 
Computational Fluid Dynamics (CFD) is the use of computers to generate information about flowing fluids under certain conditions. CFD is used to predict fluid flow in a particular system at a specified condition [8]. By using CFD, the prediction of fluid flow in various systems can be done at a cheaper cost and faster time compared to experimental methods [9-11].

\section{METHOD}

The five (5) impellers as samples, a CFD simulation process is carried out to determine the optimum characteristics, with several processes, namely [12-15]:

\subsection{Preprocessing}

Preprocessing, is the first step in developing and analyzing a CFD model, which is creating a model in a CAD (Computer Aided Design) package, creating a suitable mesh, then applying the fluid requirements and properties. The mesh function is to provide and share the fluid space of the workpiece. As for the results of the grid mesh CFD can be seen in Figure 1.

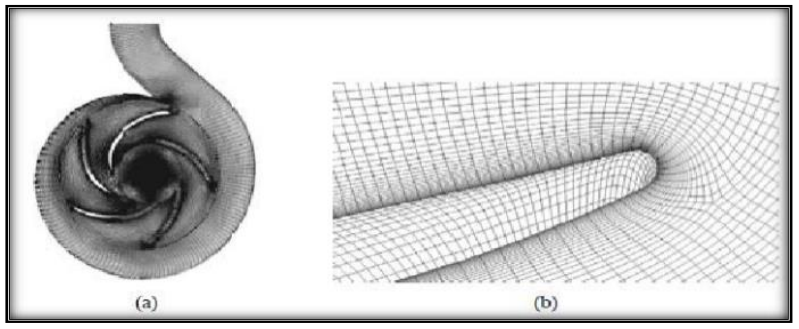

Figure 1 Domain and content distribution of control / grid mesh (a) centrifugal pump and (b) blade impeller [5]

To find out the specifications of impeller PAT used can be seen in Table 1 .

Table 1. Initial impeller specifications

\begin{tabular}{ll}
\hline Specifications & Size \\
\hline The outer diameter of the impeller is & $124 \mathrm{~mm}$ \\
The impeller inlet diameter is & $88 \mathrm{~mm}$ \\
Impeller blade outlet angle $\beta 1$ & $55^{\circ}$ \\
Impeller blade inlet angle $\beta 2$ & $89^{\circ}$ \\
Number of Blades & 6 \\
Impeller type & Forward \\
The thickness of the impeller blades is & $3.25 \mathrm{~mm}$ \\
Blades surface roughness & $0.16 \mu \mathrm{m}$ \\
\hline
\end{tabular}

\subsection{Solving}

Solving, is a Solvers (core program for finding solutions). CFD calculates the conditions applied at the time of preprocessing. Using the finite volume method.
The iteration process is to make an educated guess on the values of the variables contained in the equation, the iteration process continues until no residual error reaches a certain value until it approaches zero. If this happens, the iteration process is said to be convergent towards the desired solution. A difference value that is determined to stop the iteration process is called the convergence value. The simulation boundary condition used in CFD can be seen in Table 2.

Table 2. Properties of simulation boundary conditions

\begin{tabular}{ll}
\hline Specifications & \multicolumn{1}{c}{ Size } \\
\hline Inlet pressure or inlet velocity & $103287 \mathrm{~Pa}$ \\
Outlet pressure & $0 \mathrm{~Pa}$ \\
Fluid of material & Constant H2O \\
Solid Material & Bronze \\
Meshing count & 797675 \\
Limit of iteration & 100 \\
\hline
\end{tabular}

\subsection{Postprocessing}

Postprocessing, is the final step in CFD analysis, which is organizing and interpreting the CFD simulation result data which can be in the form of images, curves and animations of velocity magnitude and static pressure. In Figure 2 following shows the geometry of centrifugal pump housing at the inlet to be carried out by the Postprocessing.

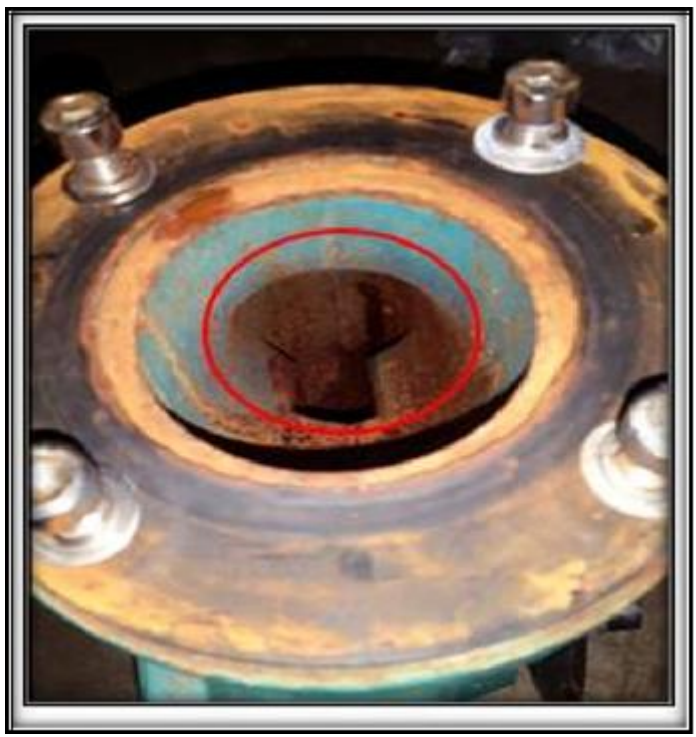

Figure 2 Geometry of centrifugal pump housing at the inlet

The result of CFD postprocessing process showing velocity magnitude and static pressure can be seen in Figure 3. 


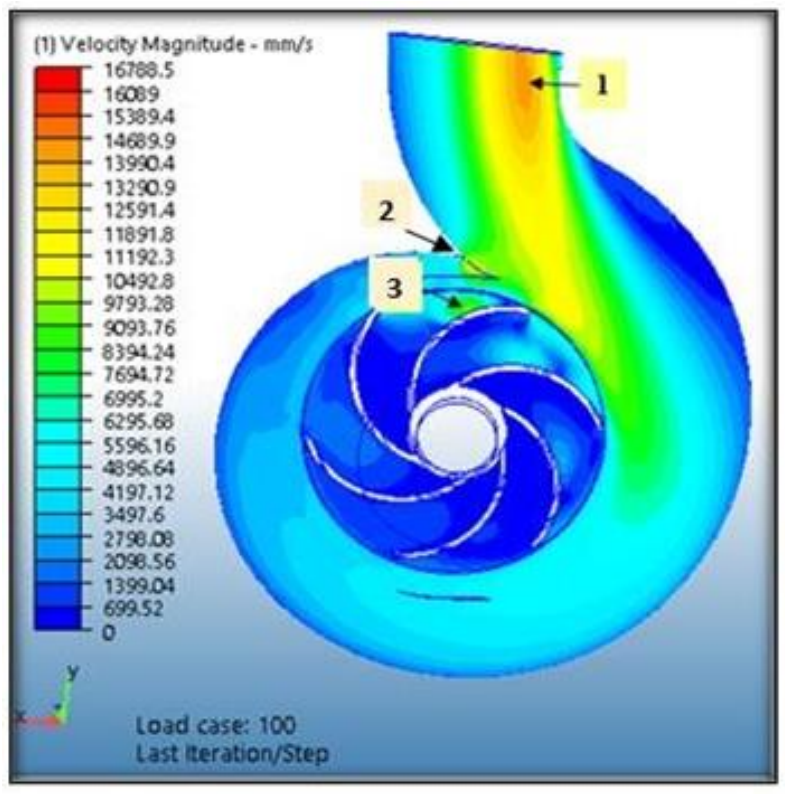

(a)

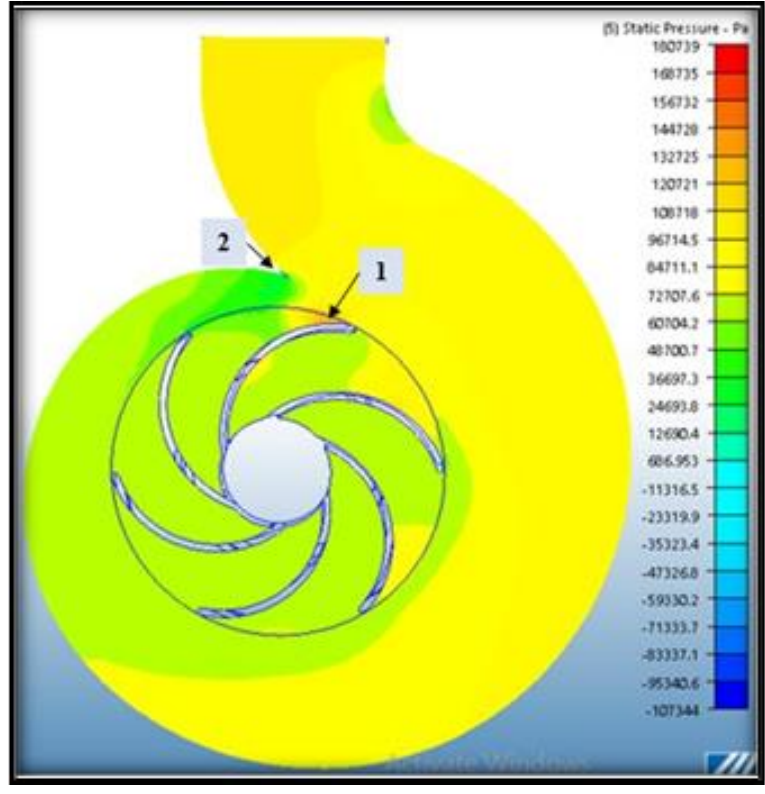

(b)

Figure 3 CFD postprocessing, (a) Velocity Magnitude contour, (b) Static Pressure

\section{RESULT AND DISCUSSION}

\subsection{Impeller Rotation}

The results of calculations from impeller centrifugal pump conducted by researcher obtained several parameters. Speed The calculation results of the impeller rotational speed and Reynold Number can be seen in the Table 3. The results of calculation speed impeller centrifugal pump with Reynold number that occur at the angle of impeller can be seen in Figure 4.

Table 3. Calculation Results of the Impeller Speed Triangle

\begin{tabular}{|c|c|c|c|c|c|c|}
\hline No & $\begin{array}{l}\text { Geometry } \\
\text { Modeling of } \\
\text { Impeller }\end{array}$ & $\begin{array}{l}\text { Speed } \\
\text { Triangle }(\boldsymbol{m} / \mathrm{s})\end{array}$ & $\begin{array}{l}\text { Calculation of } \\
\text { Impeller Speed (rpm) }\end{array}$ & $\begin{array}{l}\text { Experimental Impeller } \\
\text { Speed (rpm) }\end{array}$ & $\begin{array}{l}\text { Reynold } \\
\text { Number }\end{array}$ & $\begin{array}{l}\text { The type of flow } \\
\text { that occurs }\end{array}$ \\
\hline 1 & First & 10,14 & $1.562,40$ & 1.532 & $1.257,36$ & Laminar \\
\hline 2 & $\beta 2=36,6^{\circ}$ & 20,55 & $3.166,40$ & - & $2.548,20$ & Turbulent \\
\hline 3 & $\beta 2=46,6^{\circ}$ & 21,33 & $3.286,59$ & - & $2.664,92$ & Turbulent \\
\hline 4 & $\beta 2=56,6^{\circ}$ & 22,15 & $3.412,94$ & $3.580,7$ & $2.746,60$ & Turbulent \\
\hline 5 & $\beta 2=66,6^{\circ}$ & 21,02 & $3.238,82$ & - & $2.606,48$ & Turbulent \\
\hline
\end{tabular}

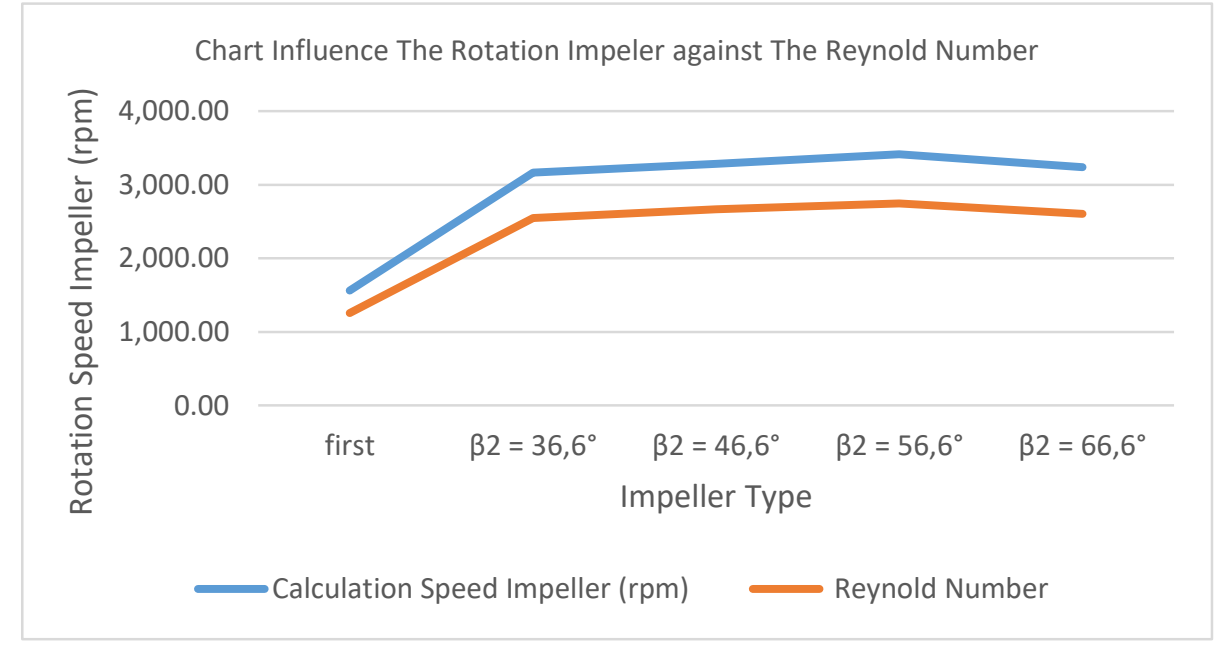

Figure 4 Graph of the effect of impeller speed on Reynold's number. 
The results of CFD simulations that have been carried out on the four backward close type impellers with the geometric model $\beta 2=36.6^{\circ}, \beta 2=46.6^{\circ}, \beta 2=56.6^{\circ}$ and $\beta 2=66.6^{\circ}$, the optimum impeller is the impeller. with the geometric model $\beta 2=56.6^{\circ}$. With the following considerations:

1. The impeller with the geometry model of the entry angle $\beta 2=56.6^{\circ}$, the value of the lowest velocity of flow / velocity magnitude, which is $8.975 \mathrm{~m} / \mathrm{s}$, the friction force that occurs between water and the impeller is small and will have an impact on the long life of the impeller.

2. The static pressure that occurs in the pump which functions as a turbine looks more homogeneous and the pressure conditions are evenly distributed so that the impeller rotation is optimum.
3. From the numerical calculation results show the impeller rotation speed, the impeller with the geometry model of the entry angle $\beta 2=56.6^{\circ}$, the highest impeller rotation speed is $3,412.94 \mathrm{rpm}$. The higher the impeller rotation value, the resulting power.

\subsection{Velocity Magnitude \& Static Pressure}

The CFD simulations that have been carried out on 5 kinds of geometric modeling on pump impellers that function as turbines, the flow characteristics that occur in a PAT with forward and backward impellers are different as shown in Table 4.

For the velocity magnitude and static pressure results of several impeller analyzed using CFD can be seen in Figure 5 below.

Table 4. CFD modeling on 5 centrifugal pump impellers on PAT.

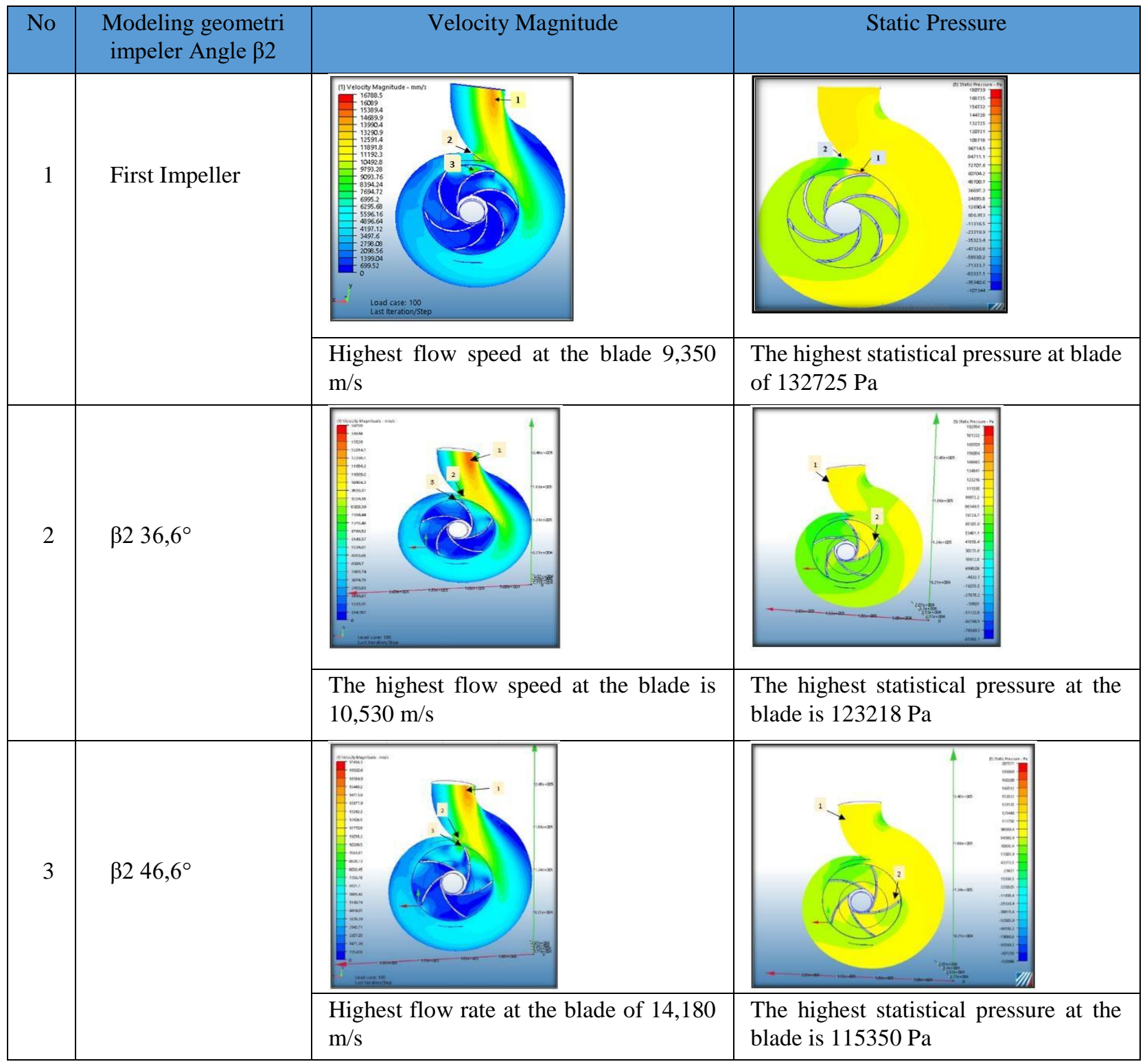




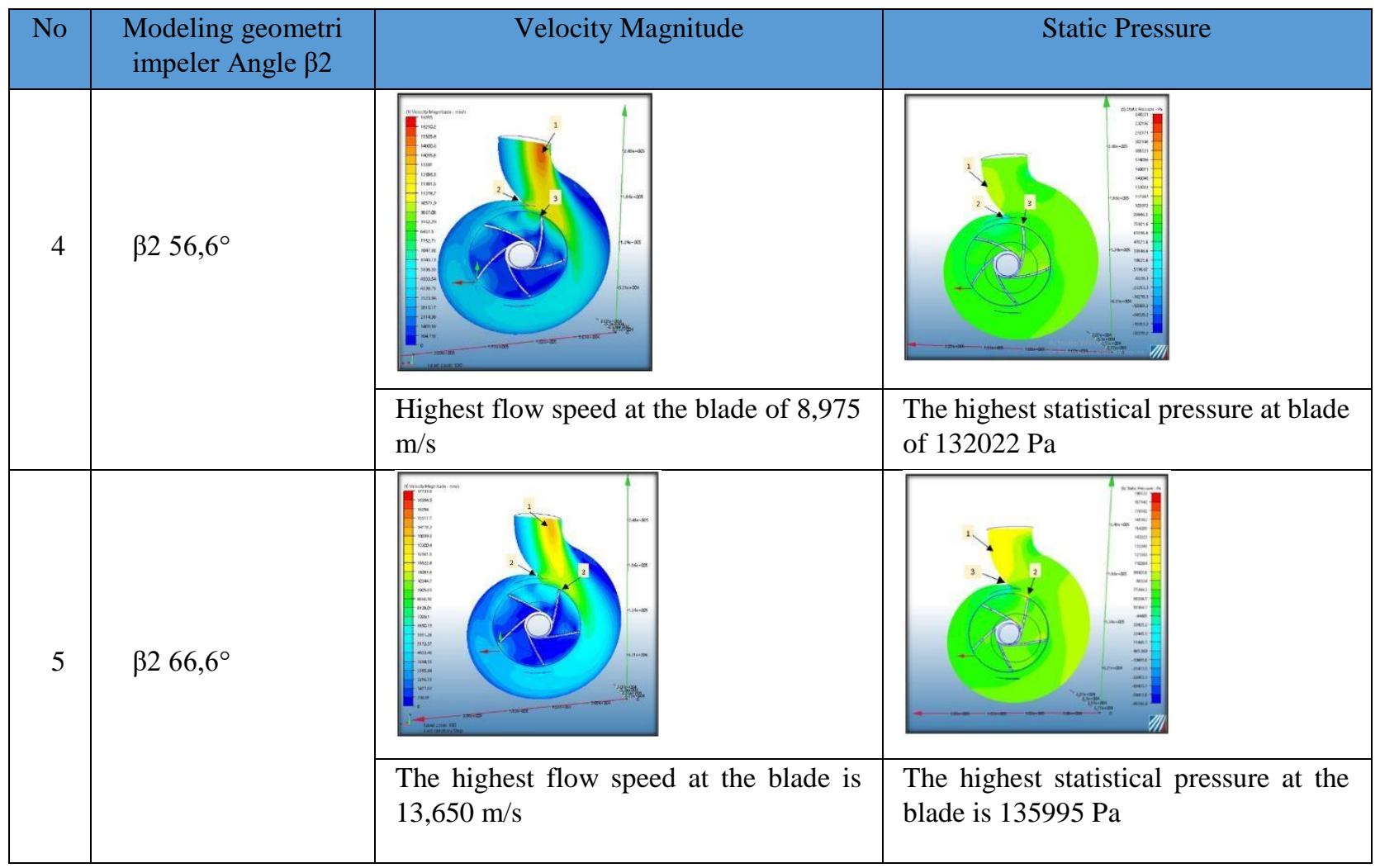

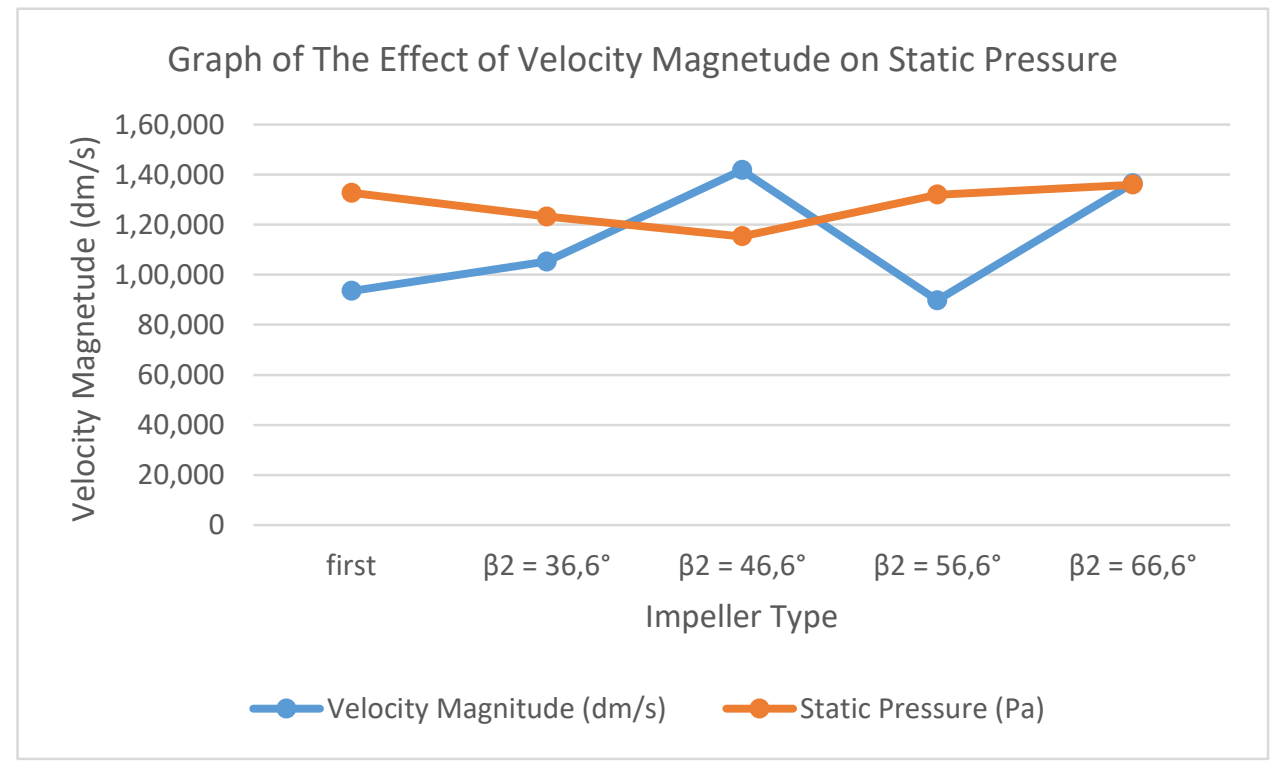

Figure 5. Graph of Velocity Magnitude influence on Pressure

The five impellers of centrifugal pump that function as turbines that have been simulated with CFD modeling as shown in Table 4.10 and Figure 4.5 , the optimum impeller is an impeller with $\beta 256.6^{\circ}$ modeling angle with several considerations:

1. The optimum velocity magnitude value is the flow rate of $8.975 \mathrm{~m} / \mathrm{s}$. In terms of strength or resistance of the impeller to flow velocity it will have a long life. Flow velocity will be directly proportional to friction force. The greater the flow velocity value, the greater the frictional force that occurs on the surface of the impeller blade.

2. The CFD simulation results at velocity magnitude are more stable than the simulation results for the other four impellers.

3. The effect of modeling changes in the shape of the entry angle $\beta 2$ will have an impact on changes in fluid flow characteristics, both flow velocity and static pressure. The greater the entry angle $\beta 2$, the more homogeneous the flow rate will be. 


\section{CONCLUSION}

Based on the results of testing and data processing obtained with CFD analysis, the following conclusions can be drawn: The impeller rotation speed has a significant increase in the backward blade closed impeller type with 5 blades with an angle of entry $\beta 2=$ $56.6^{\circ}$, which is $3,412.94 \mathrm{rpm}$ with a Reynold number of 2,746.60. The higher the rotation of an impeller, the greater the Reynold number value on the Pump As Turbine. And the lowest flow velocity value of $8.975 \mathrm{~m} /$ s occurs in the modeling of the inlet angle $\beta 2=56.6^{\circ}$, so that will affect the life time / life that is relatively longer on the impeller.

\section{ACKNOWLEDGMENTS}

The authors gratefully acknowledge to Institut Teknologi Sepuluh Nopember Surabaya for financial supporting this work through Postgraduate Research Grant 2020.

\section{REFERENCES}

[1] Rompas, Parabelem T.D. 2011. Analisis Pembangkit Listrik Tenaga Mikrohidro (PLTMH) Pada Daerah Aliran Sungai Ongkak Mongondow Di Desa Muntoi Kabupaten Bolaang Mongondow. Penelitian Saintek Vol. 16 No. 2

[2] Patel, V.A., Jain, S.V., Motwani, K.H., dan Patel, R.N., 2013. Numerical Optimization Of Guide Vanes and Reducer in Pump Running in Turbine. Procedia Engineering 51 797-802.

[3] Rusdi, Alfian. Maryono, Agus. dan Suhanan. 2014. Penelitian Efisiensi Pump As Turbine (PAT) Untuk Mendukung Perencanaan dan Implementasi PLTMH di Kabupaten Sumbawa. Asean Journal of System Engineering.

[4] Jain, Sanjay V., Swarnkar, Abhishek., Motwani, Karan H., dan Patel, Rajesh N. 2015. Effect of Impeller Diameter and Rotational Speed on Performance of Pump Running in Turbine Mode. Energy Conversion and Management 89 808-824.

[5] Hon, Lin Liu., Jian, Wang., Yong, Wang., Hua, Zhang. dan Haoqin, Huang. 2014. Influence of the Empirical Coefficients of Cavitation Model on Predecting Cavitating Flow on the Centrifugal
Pump. Int. J. Nav. Archit. Ocean. Eng 6: 119-131. pISSN: 2029-6782, eISSN:2092-6790.

[6] Sun, Sheng Yang. Hou, Lin Liu. Fan, Yu Kong. Bin, Xia. dan Lin, Wei Tan. 2014. Effects of the Radial Gap Between Impeller Tips and Volute Tongue Influencing the Performance and Pressure Pulsations of Pump as Turbine. Fluids Engineering ASME Vol. 136 / 054501-1.

[7] Agustian, Rian. 2019. Analisa Performa Pompa Sentrifugal Merk Nijhuis Dan Thorisima Selama 5 Tahun. Bachelor Thesis, Universitas Islam Majapahit Mojokerto.

[8] Fecarotta, O. Carravetta, A. dan Ramos, H. M. 2011. CFD and Comparisons for a Pump as Turbine: Mesh Reliability and Performance Concerns. International Journal of Energy and Environment. Vol. 2 Issue 1 pp. 39-48.

[9] Gazali, Amal All. 2018. Analisa Aliran Fluida Menggunakan CFD Dengan Variabel Viscosity pada Preproses Injeksi Molding.

[10] Nakayama, Y. 2009. Introduction to Fluid Mechanics. In Boucher, R. F (editor). Reading Page 41 - 53. Japan. Yokendo Co. LTD.

[11] Versteeg, H. K. dan Malalasekera, W. 1996. An Introduction to Computational Fluid Dynamics The Finite Volume Method. Versteeg, H.K. dan Malalasekera, W (editor). Reading Page 10 - 50 . Malaysia. Longman Group Ltd.

[12] Shaw, C. T. 1992. Using Computational Fluid Dynamics. In Shaw, C. T (editor). Reading Page 210 - 260. Prentice Hall.

[13] Anagnostopoulos, John S. 2009. A Fast Numerical Method For Analysis and Blade Design in Centrifugal Pump Impellers. Computers \& Fluids Vol. $38284-289$.

[14] Ming, Zhang. Yan, Liu. Weiqiang, Wang. Pengfei, Wang. dan Jianfeng, Li. 2016. The Fatigue of Impellers and Blades. Engineering Failure Analysis. Vol. xxx xxx-Xxx.

[15] Sumardi, Mohamad. 2016. Kajian Eksperimental Modifikasi Geometri Rounding dan Kekasaran Permukaan Impeler Pump As Turbine pada Pembangkit Listrik Tenaga Mikrohidro. Tesis. 